\title{
ENCONTRO DA ASSOCIAÇÃO DE PROFESSORES \\ DE LÍNGUA E LITERATURA (APLL) - LÍNGUA, LITERATURA E INCLUSÃO SOCIAL
}

\author{
Elis de Almeida Cardoso*
}

Nos dias 13 e 14 de dezembro de 2007, na sala 8 do Prédio de Ciências Sociais (FFLCH-USP), ocorreu o Ciclo de Palestras intitulado Lingua, Literatura e Inclusão Social.

O evento, organizado pela diretoria da APLL, teve por principal objetivo discutir o tema da inclusão social, associando-o ao ensino de Língua e de Literatura, aproximando, dessa forma, professores universitários e pesquisadores de professores da rede pública e particular de ensino.

As quatro mesas-redondas - Práticas de Ensino de Língua Oral e Escrita; Língua, Cultura e Ensino; Linguagem e Intolerância; Violência e Discurso - contaram com a presença de renomados professores que desenvolvem seus trabalhos e suas pesquisas em diferentes áreas.

As palestras de Norma Seltzer Goldstein (FFLCH/USP) - Gêneros e ensino de língua materna -, Maria Valíria Aderson de Mello Vargas (FFLCH/USP) - Práticas discursivas e ensino de língua portuguesa: as marcas temporais e aspectuais nos enunciados orais e escritos - e Zilda Gaspar Oliveira de Aquino (FFLCH/USP) - As relações entre oralidade e escrita no ensino de língua portuguesa - abriram o evento, levando o público a refletir a respeito do estudo dos gêneros discursivos e sua a relação com o ensino de língua oral e escrita.

Para discutir a respeito de Língua, Cultura e Ensino, compuseram a segunda mesaredonda Maria Helena da Nóbrega (FFLCH/USP) - Português Instrumental: textos em harmonia -, Luiz Costa Pereira Junior (FE/USP e Revista Língua Portuguesa) Contemporaneidade e cultura na língua - e Maria Vicentina de Paula do Amaral Dick (FFLCH/USP) - Os estudos toponímicos no ensino.

Linguagem e Intolerância foi o título da mesa-redonda que proporcionou ao público importantes reflexões sobre como aceitar a diversidade cultural, racial e sexual e evitar o preconceito lingüístico e social. Compuseram a mesa os professores Marli Quadros Leite (FFLCH/USP) - Manifestações de preconceito e intolerância lingüísticos pela imprensa -, Mamede Mustafá Jarouche (FFLCH/USP) - Antiarabismo - e Emerson da Cruz Inácio (FFLCH/USP) - Para um Cânone da Diversidade: negros, gays, mulheres $e$ marginalizados invadem a sala de aula.Finalizando o Ciclo e Palestras, debateu-se sobre uma importante questão: a necessidade de se trabalhar com o tema da violência em sala de aula. Participaram dessa discussão Jaime Ginzburg (FFLCH/USP) - O discurso da violência na imprensa escrita -, Ana Rosa Ferreira Dias (FFLCH/USP) - Violência, indústria cultural e literatura e Eduardo Brito (NEV) - Discutindo violência na sala de aula através da literatura.

\footnotetext{
* Presidente da Associação de Professores de Língua e Literatura (APLL). Prof ${ }^{a}$ Dr $^{a}$ da Área de Filologia e língua Portuguesa. DLCV/FFLCH/USP.
} 